SAINS TANAH - Journal of Soil Science and Agroclimatology

Journal homepage: http://jurnal.uns.ac.id/tanah

\title{
Sustainability performance of organic farming at vegetable fields in Tabanan, Bali, Indonesia
}

\author{
I Ketut Sardiana, Tati Budi Kusmiyarti* \\ Department of Agroecotechnology, Faculty of Agriculture, University of Udayana, Bali, Indonesia
}

\begin{tabular}{|c|c|}
\hline ARTICLE INFO & ABSTRACT \\
\hline Keywords: & ustainable agriculture aims to maintain high productivity while maintaining soil quality. \\
\hline farming system & ne purpose of this study is to determine the sustainability performance of $c$ \\
\hline Soil quality & egetable farming systems with soil quality indicators as a soil quality assessment tool. Soil \\
\hline Sustainability of agriculture & nysical, chemical, and biological properties in Chinese cabbage in Baturiti Subdistrict, \\
\hline system & $\begin{array}{l}\text { Tabanan Regency, Bali, Indonesia, were evaluated as indicators for predicting organic } \\
\text { cabbage production and yield. Soil samples were obtained from organic farming systems }\end{array}$ \\
\hline Article history & that have been going on for 1,3 , and 5 years after certification, compared with \\
\hline Submitted: 2020-11-09 & onventional farming systems. The results showed that the soil quality of the organic \\
\hline Accepted: 2021-04-14 & farming system after 5 years (OF5) was significantly higher than the conventional farming \\
\hline Available online: $2021-$ & system. Physically, soil moisture at the field capacity in OF5 was significantly higher than \\
\hline Published regularly: June 202 & $\begin{array}{l}\text { that in the other systems. Chemically, the organic } C \text { and cation exchange capacity in organic } \\
\text { systems were significantly higher than in conventional systems. The same results were }\end{array}$ \\
\hline$* C$ & shown by soil respiration, which means that there was high soil microbial activity. Based \\
\hline $\begin{array}{l}\text { Email address } \\
\text { tatibudi@unud }\end{array}$ & $\begin{array}{l}\text { on the cumulative soil quality rating, it is concluded that the OF5 system met the } \\
\text { sustainability criteria, with no high input required. }\end{array}$ \\
\hline
\end{tabular}

How to Cite: Sardiana, I. K., \& Kusmiyarti, T. B. (2021). Sustainability performance of organic farming at vegetable fields in Tabanan, Bali, Indonesia [Research]. Sains Tanah Journal of Soil Science and Agroclimatology, 18(1): 8-15. https://dx.doi.org/10.20961/stjssa.v18i1.45482

\section{Introduction}

Organic farming is a system that increases soil fertility using natural inputs without the use of chemical fertilizers and pesticides (Chabert \& Sarthou, 2020; Seufert et al., 2012). However, organic farming (OF) remains to be considered by some critics as an inefficient approach for food security and a farming system that will become less relevant in the future. OF emerged as a response to agricultural industrialization and environmental and social problems. Nevertheless, it is debatable whether OF provides an overall advantage over conventional farming (CF). Some people claim that OF systems are more profitable and environmentally friendly (Reganold \& Wachter, 2016), whereas others question the role of OF in future sustainable food systems (Röös et al., 2018). Although yields usually remain lower than those in conventional agriculture, OF currently performs well in several sustainability domains, such as animal welfare, agricultural profitability, and low pesticide use (Chabert \& Sarthou, 2020; Röös et al., 2018).
The sustainability of agricultural systems can be determined via the concept of minimum data sets with soil quality assessment. The soil quality is measured using the indicators of soil quality or the attributes influenced by land use and soil management practices. The indicators comprise physical, chemical, and biological characteristics (DomínguezHaydar et al., 2019). Thus, the criteria of soil quality are determined using the critical threshold of each soil property based on the turning point of the decrement of productivity and environmental impacts (Ghaemi et al., 2014; Nabiollahi et al., 2018).

Patil et al. (2014) determined the sustainability performance of OF in Karnataka, India from 2009 and 2015 using the TechnoGIN method and found that sustainability performance depends on region conditions and cultivated crops. Das et al. (2017) found that OF resulted in sustainable productivity and improved soil quality by assessing the longterm impacts of OF on soil and commodities quality for 7 
years in the eastern Himalayas, India. Then, Boone et al. (2019) compared the performance of conventional and OF systems and confirmed that OF has shown benefits in terms of more environmentally friendly practices and sustainability performance over time that has continued to increase for soil quality. OF practices foster biotic and abiotic interactions in the soil, which may facilitate moving toward a sustainable food future (Sihi et al., 2017) and can be a viable measure that contributes to greenhouse gas alleviation in the agricultural sector (Skinner et al., 2019).

The OF practices in Indonesia, particularly in Bali, have significantly increased but to date, there is no information regarding the sustainability performance assessment of OF in Bali. The total area of organic land has reached 261,383 ha, increasing by an average of $5.5 \%$ per year (Sardiana et al., 2014). Thus, this study is aimed to determine the sustainability of OF systems, especially in vegetable fields in Tabanan, Bali. The sustainability of this OF system depends on the soil quality rating (SQR) value, which is determined by the cumulative score and rate from the minimum dataset of soil properties. This means that the level of sustainability is reflected in the soil properties that meet the sustainability criteria.

\section{Material and Methods}

The experimental research was conducted in the Baturiti Subdistrict, Tabanan Regency, Bali, Indonesia, at an altitude of $975 \mathrm{~m}$ above sea level (Figure 1). The location of the present study has an Andosols with a tropical climate, an average temperature of $21^{\circ} \mathrm{C}-31^{\circ} \mathrm{C}$, and an average rainfall of $3,165.11 \mathrm{~mm}$ (Sardiana et al., 2014). The sample locations were selected on land that has received 1 year of OF certification (located at $8^{\circ} 33^{\prime} 54^{\prime \prime} S$; $115^{\circ} 17^{\prime} 22^{\prime \prime} \mathrm{E}$ ), 3 years (at $8^{\circ} 33^{\prime} 57^{\prime \prime S}$; $115^{\circ} 17^{\prime} 27^{\prime \prime} \mathrm{E}$ ) and 5 years (located at $8^{\circ} 33^{\prime} 55^{\prime \prime} \mathrm{S}$; $115^{\circ} 17^{\prime} 23^{\prime \prime} \mathrm{E}$ ) and for comparison, selected on land that was still applied with conventional agriculture (located at $8^{\circ} 33^{\prime} 54^{\prime \prime S}$; $115^{\circ} 17^{\prime} 22^{\prime \prime} \mathrm{E}$ ). Four experimental units were used to assess the effect of land management methods on the soil's physical, chemical, and biological properties. Then, to determine the level of production in each plot, an experiment was conducted on planting Chinese cabbage (Brassica chinensis).

\subsection{Management Practices}

Several activities were conducted at the experimental location, including soil tillage, which is carried out by plowing at a depth of $20 \mathrm{~cm}$. Organically cultivated land was given manure with a dose of $10-20$ tons $\mathrm{ha}^{-1}$. The nutritional composition of cow manure is $\mathrm{C}(17.36 \%), \mathrm{N}(1.16 \%), \mathrm{P}(0.53 \%)$, and $\mathrm{K}(0.14 \%)$. Meanwhile, in the conventional systems, fertilization with superphosphate (SP-36, $200 \mathrm{~kg} \mathrm{ha}^{-1}$ ) and potassium chloride $\left(\mathrm{KCl}, 100 \mathrm{~kg} \mathrm{ha}^{-1}\right)$, and urea $\left(\mathrm{CH}_{4} \mathrm{~N}_{2} \mathrm{O}, 400 \mathrm{~kg}\right.$ $\left.\mathrm{ha}^{-1}\right)$ were applied.

\subsection{Soil Sampling and Analyses}

Soil samples were taken in September 2018 with a depth ranged $0-20 \mathrm{~cm}$ repeated four times in each experimental plot. Field capacity was determined via a gravimetric technique, and soil texture (ST) was determined using the sieve analysis, soil acidity measured using a $\mathrm{pH}$ meter; $\mathrm{C}$ and $\mathrm{N}$ on soil were determined using the Walkley-Black and Macro-Kjeldahl methods, respectively. Cation exchange capacity (CEC) and base saturation (BS) were determined via the $\mathrm{NH}_{4} \mathrm{OAc}$ extraction method (Sparks et al., 2020). Conversely, the measurements of total soil respiration (SP) were performed via Iser Meyer's $\mathrm{CO}_{2}$ evolution method (Bakhshandeh et al., 2019; Franzluebbers \& Veum, 2020; Gu \& McGill, 2017).

At the planting sites, plants were cut manually from an area of $1 \mathrm{~m} \times 1.6 \mathrm{~m}$, used to compare the physical, chemical, and biological properties of the soil to the biomass yield. The dry base moisture content of the biomass was measured by comparing biomass fresh weight with oven-dry weight (dried at $60^{\circ} \mathrm{C}$ for 4 days). The Chinese cabbage (Brassica chinensis) was used as an indicator plant in the present study.

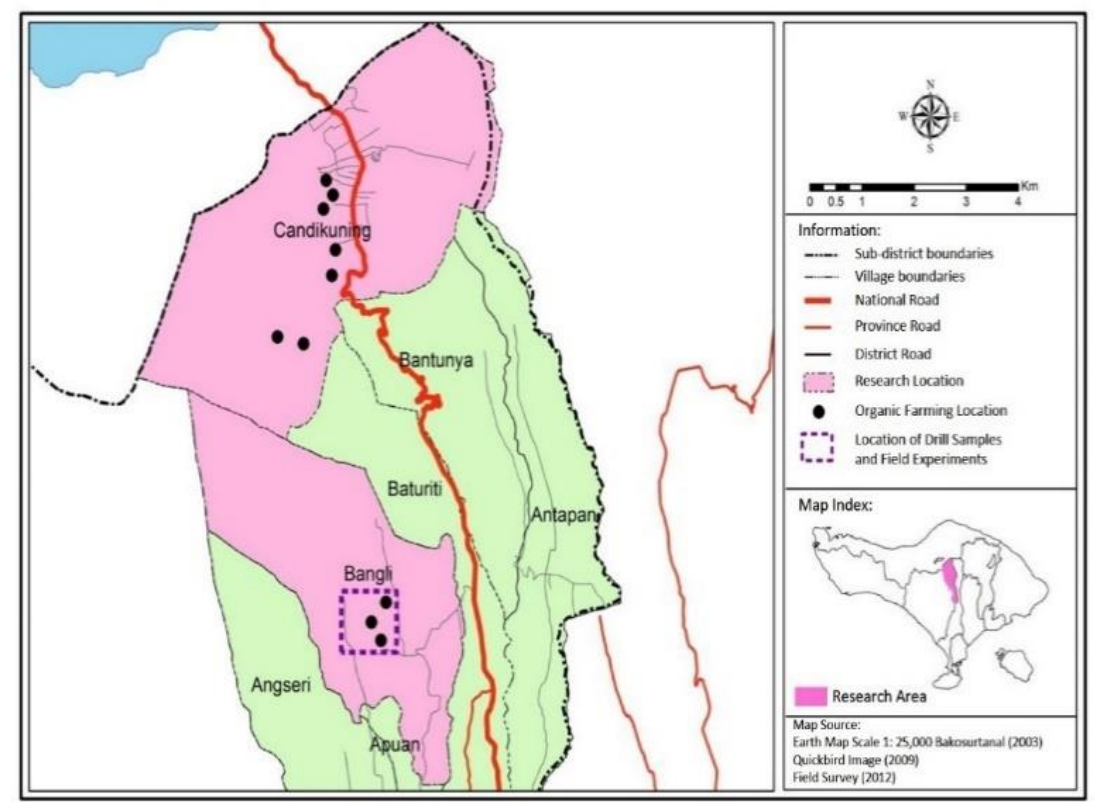

Figure 1. Research site in Baturiti Subdistrict, Tabanan Regency, Bali, Indonesia 
Table 1. Critical levels and relative weighting factors (RWF) for soil physical, chemical, and biological properties (Ghaemi et al., 2014).

\begin{tabular}{|c|c|c|c|c|c|c|}
\hline \multirow{3}{*}{ No. } & \multirow{3}{*}{ Soil quality indicator } & \multicolumn{5}{|c|}{ Limitation and relative weighting factor } \\
\hline & & None & Light & Moderate & Severe & Extreme \\
\hline & & 1 & 2 & 3 & 4 & 5 \\
\hline 1 & Field capacity (\%) & $>30$ & $20-30$ & $8-20$ & $2-8$ & $<2$ \\
\hline 2 & Bulk density $\left(\mathrm{g} / \mathrm{cm}^{3}\right)$ & $<1.3$ & $1.3-1.4$ & $1.4-1.5$ & $1.5-1.6$ & $>1.6$ \\
\hline 3 & Soil pores (\%) & $>20$ & $18-20$ & $15-18$ & $10-15$ & $<10$ \\
\hline 4 & Soil texture & $\mathrm{L}$ & SiL, Si, SiCL & $\mathrm{CL}, \mathrm{SL}$ & SiC, LS & $\mathrm{S}, \mathrm{C}$ \\
\hline 5 & Soil organic carbon (\%) & $5-10$ & $3-5$ & $1-3$ & $0.5-1$ & $<0.5$ \\
\hline 6 & Nitrogen total (\%) & $>0.75$ & $0.51-0.75$ & $0.21-0.50$ & $0.10-0.20$ & $<0.10$ \\
\hline 7 & $\mathrm{CEC}\left(\mathrm{mmol} \mathrm{kg}^{-1}\right)$ & $>40$ & $25-40$ & $17-24$ & $5-16$ & $<5$ \\
\hline 8 & $\mathrm{pH}$ & $6.0-7.0$ & $\begin{array}{c}5.8-6.0 \text { or } \\
7.0-7.4\end{array}$ & $\begin{array}{c}5.4-5.8 \text { or } \\
7.4-7.8\end{array}$ & $\begin{array}{c}5.0-5.4 \text { or } \\
7.8-8.2\end{array}$ & $<5.0$ or $>8.2$ \\
\hline 9 & Base saturation (\%) & $>70$ & $51-70$ & $36-50$ & $20-35$ & $<20$ \\
\hline 10 & $\mathrm{SR} \mathrm{bsCO}{ }_{2}-\mathrm{C} / \mathrm{ac} / \mathrm{hr}$ & $>64$ & $33-64$ & $17-32$ & $3.5-16$ & $<3.5$ \\
\hline
\end{tabular}

Remarks: $\mathrm{CEC}=$ cation exchange capacity; $\mathrm{SR}=$ soil respiration; $\mathrm{L}=$ loam; SiL= silt loam; $\mathrm{Si}=$ silt; $\mathrm{SiCL}=$ silty clay loam; $\mathrm{CL}=\mathrm{clay}$; $\mathrm{SL}=$ sandy loam; $\mathrm{SiC}=$ silty clay; $\mathrm{LS}=$ loamy sand; $\mathrm{S}=$ sand; $\mathrm{C}=$ clay

Table 2. Sustainability of a land use and management system in relation to the cumulative ratings (CRs) (Ghaemi et al., 2014)

\begin{tabular}{lcc}
\hline Sustainability & RWF & CR \\
\hline Highly sustainable & 1 & $<20$ \\
Sustainable & 2 & $20-25$ \\
Sustainable with high input & 3 & $25-30$ \\
Sustainable with another land use & 4 & $30-40$ \\
Unsustainable & 5 & $>40$ \\
\hline
\end{tabular}

Remarks: RWF = relative weighting factors; $\mathrm{R}=$ cumulative ratings

\subsection{Critical Limits and Sustainability Index}

The critical limits of physical, chemical, and biological soil properties used in the study refer to the soil quality criteria for tropical ecosystems. The critical level is determined based on the limited production of food crops, which ranges from none (one) to an extreme (five) (Table 1). Table 1 also describes 10 soil property indicators in the form of physical, chemical, and biological properties tested in this research, which is the minimum data set that can describe SQR as a determinant of land sustainability for agricultural use. The sustainability index is obtained by adding up the critical levels for each physical, chemical, and biological soil properties shown in Table 2, with cumulative rating (CR), which ranges from being sustainable $(C R<20)$ to being unsustainable $(C R>40)$
(Assunção et al., 2019; Maini et al., 2020; Nabiollahi et al., 2018; Srivastava et al., 2020). A QR value of $<20$ indicates that there are fewer soil properties that limit plant growth and production. In another sense, the existing soil properties support plant growth and production. A CR value of $<20$ also illustrates that the land can be sustainably used for agriculture because of its high SQR value. Conversely, with a CR value of $>40$, the soil characteristics limit the growth and production of plants, making the soil not suitable for agricultural use

\subsection{Statistical Analysis}

Correlation analysis, using SPSS Ver. 17 for Windows software, was applied to identify the relationship between the 10 soil properties and the soil quality, as well as to determine the sustainability of the farming systems based on the soil property rating index. The 10 soil properties used for correlation analysis including bulk density (BD), soil texture $(\mathrm{ST})$, soil field capacity (FC), soil porosity (SP), $\mathrm{pH}$, soil organic carbon (SOC), total N, CEC, BS, and SR. To obtain the relationship between the biomass yield and the 10 selected soil properties, multiple linear regression analysis, with a significance level of $\mathrm{P} \leq 0.05$, was performed with biomass and soil properties as the dependent and independent variables, respectively (Abrougui et al., 2019; Ge \& Wu, 2020; Jiang et al., 2019; Kadam et al., 2019; Lee et al., 2019).

Table 3. Physical properties of soil in organic and conventional agriculture for 5 years of application

\begin{tabular}{|c|c|c|c|c|c|c|c|}
\hline \multirow{2}{*}{ Treatment } & \multirow{2}{*}{$\mathrm{BD}\left(\mathrm{g} \mathrm{cm}^{-3}\right)$} & \multirow{2}{*}{ SP (\%) } & \multirow{2}{*}{ FC (\%) } & \multicolumn{4}{|c|}{ Texture } \\
\hline & & & & Sand (\%) & Silt (\%) & Clay (\%) & Class \\
\hline OF5 & $0.88^{a}$ & $26.88^{a}$ & $32.88^{a}$ & $52.86^{a}$ & $29.88^{a}$ & $18.26^{\mathrm{a} 1)}$ & $\mathrm{SL}^{2)}$ \\
\hline OF3 & $0.90^{\mathrm{a}}$ & $25.20^{\mathrm{a}}$ & $29.03^{\text {ba }}$ & $60.45^{a}$ & $24.23^{\mathrm{a}}$ & $14.57^{a}$ & SL \\
\hline OF1 & $0.91^{a}$ & $23.61^{a}$ & $27.00^{\text {ba }}$ & $61.73^{a}$ & $24.49^{a}$ & $15.33^{\mathrm{a}}$ & SL \\
\hline $\mathrm{CF}$ & $1.04^{\mathrm{a}}$ & $23.33^{a}$ & $24.43^{b}$ & $65.15^{a}$ & $21.28^{\mathrm{a}}$ & $13.78^{a}$ & SL \\
\hline
\end{tabular}

Remarks: ${ }^{1)}$ The value followed by the same superscript in the same column was not significantly different in the LSD test at $\alpha=5 \%(P>0.05) ;{ }^{2)} \mathrm{SL}=$ sandy loam 
Table 4. Chemical and biological properties of soil in conventional and organic farming for 5 years of application

\begin{tabular}{ccccccc}
\hline Farming system & Organic C $(\%)$ & Total N (\%) & $\left.\mathrm{CEC}(\mathrm{mmol} \mathrm{kg})^{-1}\right)$ & $\mathrm{BS}(\%)$ & $\mathrm{pH}$ & $\mathrm{SR} \mathrm{mg-CO}_{2} \mathrm{~kg}^{-1} \mathrm{day}^{-1}$ \\
\hline OF5 & $3.20^{\mathrm{a}}$ & $0.32^{\mathrm{a}}$ & $10.90^{\mathrm{a}}$ & $11.36^{\mathrm{a}}$ & $6.95^{\mathrm{a}}$ & $76.90^{\mathrm{a}}$ \\
OF3 & $2.73^{\mathrm{ba}}$ & $0.27^{\mathrm{b}}$ & $10.33^{\mathrm{ba}}$ & $10.82^{\mathrm{a}}$ & $6.75^{\mathrm{a}}$ & $68.30^{\mathrm{bc}}$ \\
OF1 & $2.54^{\mathrm{ba}}$ & $0.25^{\mathrm{b}}$ & $9.71^{\mathrm{ba}}$ & $9.98^{\mathrm{a}}$ & $6.65^{\mathrm{a}}$ & $66.00^{\mathrm{bc}}$ \\
CF & $2.26^{\mathrm{b}}$ & $0.33^{\mathrm{a}}$ & $8.98^{\mathrm{b}}$ & $9.87^{\mathrm{a}}$ & $6.62^{\mathrm{a}}$ & $54.80^{\mathrm{c}}$ \\
\hline
\end{tabular}

Remarks: The value followed by the same superscript in the same column was not significantly different in the LSD test at $\alpha=$ $5 \%(P>0.05)$

Table 5. Correlation of the implementation of organic farming systems with soil characteristics and crop yields

\begin{tabular}{|c|c|c|}
\hline Variable & \multicolumn{2}{|c|}{$\begin{array}{c}\text { Correlation coefficient } \\
\text { (r) }\end{array}$} \\
\hline \multicolumn{3}{|l|}{ Soil property } \\
\hline - SOC & 0.85 & $*$ \\
\hline$-\quad N$ & 0.86 & $*$ \\
\hline$-P$ & 0.40 & \\
\hline$-\quad K$ & 0.59 & \\
\hline - CEC & 0.88 & $*$ \\
\hline$-\quad B S$ & 0.13 & \\
\hline$-\quad p H$ & 0.57 & \\
\hline$-\quad S R$ & 0.55 & \\
\hline$-\quad F C$ & 0.78 & $*$ \\
\hline$-\quad B D$ & -0.39 & \\
\hline$-\quad S P$ & 0.32 & \\
\hline Yields & 0.92 & $* *$ \\
\hline \multicolumn{3}{|c|}{$\begin{aligned} & \text { Remarks: } * \text { significant at } \alpha=0.05 ; * * \text { highly significant } \\
& \alpha=0.01 ; \mathrm{FS}=\text { farming system; } \mathrm{FC}=\text { water content } \\
& 30 \mathrm{kpa} ; \mathrm{BS}=\text { base saturation; } \mathrm{BD}=\text { bulk density } \\
& \mathrm{SR}=\text { soil respiration; } \mathrm{CEC}=\text { cation exchange capacity } \\
& \mathrm{N}=\text { nitrogen; } \mathrm{P}=\text { phosphate } \mathrm{K}=\text { potassium; } \mathrm{SP}=\text { soi } \\
& \text { porosity }\end{aligned}$} \\
\hline
\end{tabular}

\section{Results}

\subsection{Soil Physical Properties}

Table 3 presents the effects of land managed organically on soil physical properties. It is shown that the soil texture is sandy loam in both the conventional and organic systems. In Table 3, it is shown that the FC of OF5 was $32.88 \%$, which was significantly higher than that in cropping systems. However, it was relatively insignificant $(P<0.05)$ compared with OF1, which was $29.03 \%$, and OF3, which was $27.00 \%$. The application of organic agriculture showed a significant correlation with the increase in FC, i.e., $0.78(\alpha=0.05)$ (Table 5). Moreover, Table 3 shows that the BD tends to decrease with the length of time during which OF systems are implemented, whereas SP tends to increase.

\subsection{Soils Chemical and Biological Properties}

Table 4 presents the effects of land managed organically on soil chemical and biological properties. Soil chemical properties such as CEC and BS showed in Table 4, its significant increase, CEC-OF5 $\left(10.90 \mathrm{mmol} \mathrm{kg}^{-1}\right)$ with CEC-CF (8.98 mmol kg-1), CEC-OF5 (11.36 mmol kg-1) with CF-OF5 $\left(9.87 \mathrm{mmol} \mathrm{kg}^{-1}\right)(\mathrm{P}<0.05)$, whereas the $\mathrm{pH}$ was not differ. At the beginning of the application of organic agriculture, the total $\mathrm{N}$ content of soil decreased, i.e., OF1 of $0.27 \%$ and OF3 of $0.25 \%$, but then increased again after 5 years of implementation of the system, i.e., CF5 of $0.32 \%$ and almost the same total $\mathrm{N}$ content than that in the conventional system, i.e., CF (0.33\%). Table 5 shows that the application of organic agriculture significantly increases the total $\mathrm{N}$ soil, $r=0.86(\alpha=0.05)$. Meanwhile, the SR in OF5 of $76.90 \%$ is significantly higher than that in $\mathrm{CF}$, which indicated the highest soil biological activity $(P<0.05)$.

\subsection{Crop Yield}

Figure 2 presents the effects of the OF application on the yield of Chinese cabbage. Crop production was determined from the top dry weight of the plant that was dried at $60^{\circ} \mathrm{C}$ for 4 days. As indicated by the dry weight of the leaves, crop production in all experimental plots in the all-OF treatments was lower than that in the CF treatments. However, the yield of cabbage in OF5 treatment of 26.78 tons ha ${ }^{-1}$ was relatively the same as that in CF treatment of 27.33 tons $\mathrm{ha}^{-1}$, whereas the OF1 treatment was $48.47 \%$ lower and the OF3 treatment was $28.64 \%$ lower than CF treatments (significantly different in the LSD test at $5 \%$ level, $P>0.05$ ). It shows that crop yields in OF practices that have lasted 5 years after certification are close to those in CF practices.

\subsection{Critical Levels of Measured Soil Properties}

Table 6 presents the index for the sustainability of agricultural land use based on the agricultural system application. Table 3 shows the critical levels for BD, SP, ST, and FC. Conversely, Table 4 shows the $\mathrm{pH}, \mathrm{SOC}$, total N, CEC, BS, and $S R$ values. Soil properties were weighed and summed for each location, as well as a CR was obtained for each plot of land. Conventional land (CF) has the highest CR ( $25 \pm 1.2)$, whereas the lowest CR was obtained for OF5 ( $C R=20 \pm 1.5$ ).

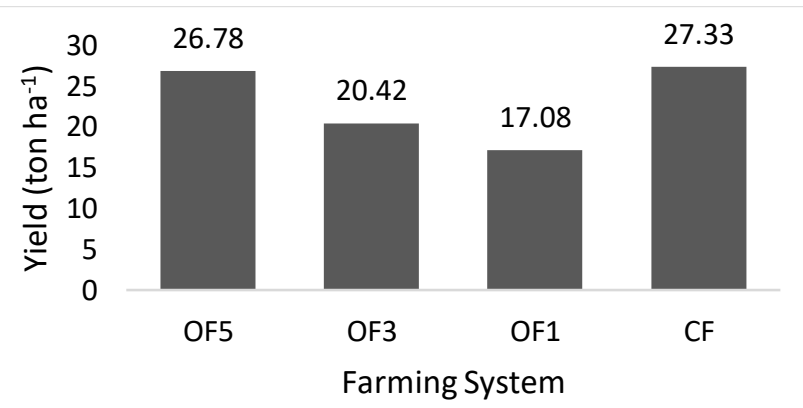

Figure 2. Yield of Chinese cabbage (Brassica chinensis) in organic and conventional farming systems (Remarks: OF1 = organic farming system that has been going on for 1 year after certification; OF3 = for 3 years; OF5 = for 5 years; $\mathrm{CF}=$ conventional farming; significantly different in the LSD test at 5\% level $(P>0.05))$. 
Table 6. Cumulative value (CR) and sustainable use of agricultural land

\begin{tabular}{lcl}
\hline $\begin{array}{c}\text { Agricultural } \\
\text { system }\end{array}$ & $\begin{array}{c}\text { Cumulative } \\
\text { rating (CR) }\end{array}$ & \multicolumn{1}{c}{ Criteria } \\
\hline OF5 & $20 \pm 1.5$ & Sustainable \\
OF3 & $24 \pm 1.9$ & Sustainable with high input \\
OF1 & $24 \pm 2.3$ & Sustainable with high input \\
CF & $25 \pm 1.2$ & Sustainable with high input \\
\hline
\end{tabular}

Remark: The CR values are as per the calculation of Ghaemi et al. (2014).

Then, the CR of OF1 and OF3 are $24 \pm 2.3$ and $24 \pm 1.9$, respectively. The variation in the cumulative value was described to be OF5 < OF3 < OF1 < CF. Thus, the sustainability index showed that OF5 is sustainable, whereas OF3, OF1, and $\mathrm{CF}$ are sustainable with high input.

\subsection{Correlation Among Application With Soil Properties}

Table 5 shows the correlation of OF system application with soil properties and crop yield. The application of OF was highly significantly correlated $(P<0.01)$ with the crop yield $(r=0.92)$ and significantly correlated $(P<0.05)$ with SOC $(r=0.85)$, CEC $(r=0.88)$, total $N(r=0.86)$, and FC $(r=0,78)$, and soil organic $C$ showed a positive correlation with SP $(r=0.32)$ and $S R(r=0.55)$. Meanwhile, an increase in SOC was reported to decrease BD. This study shows that SOC was inversely proportional to BD $(r=-0.39)$, which showed a decrease in $\mathrm{BD}$ with an increasing organic matter content.

\section{Discussion}

The CR classification in Table 2 according to (Ghaemi et al., 2014) resulted in the sustainability criteria presented in Table 6 , shows that in the 5 years of OF system (OF5) was included in the sustainable classification, $C R=20 \pm 1.5$, whereas the $C F$ system was included in sustainable classification with high input ( $C R=25 \pm 1.2$ ). The results showed that the application of OF had a significant effect on improving soil quality and the sustainability of the agricultural system. The characterized by several selected soil quality indicators such as the moisture content of the field potential (Table 3), SOC and CEC (Table 4) significantly increased in OF5. The improvement of soil quality parameters in OF is related to the increase in soil organic matter. Soil organic $C$ is highly reactive, controls various essential functions, and affects soil quality and productivity (Nurhidayati et al., 2018).

Organic matter increases the water holding capacity and the availability of water necessary for plant growth. When applied to the soil, it causes weathering and overhauling, which eventually produces humus (Güldner \& Krausmann, 2017). Also, it is hydrophilic given that it increases the water absorption in the soil and causes high water retention. Humus can absorb water 4-6 times its weight, which plays a role in water availability (Singh et al., 2020). Obour et al. (2018) reported that the percentage of organic matter is directly related to soil water absorption capacity. Meanwhile, the addition of organic matter to sandy soils increases mediumsized pores and reduces macropores, thereby increasing the soil's ability to retain water. Conversely, the added organic matter application increases the total pore soil and reduces soil BD (Liu et al., 2017).

Table 3 shows the effects of the land managed organically on soil physical properties. The role of SOC in improving the soil's physical properties is to create aggregation or form pores; therefore, it reduces the soil BD (Olorunfemi et al., 2020; Zhang et al., 2017). Compared with CF, OF has shown a decrease in BD soil by $19.93 \%$ for 5 years, i.e., OF5 $(0.88 \mathrm{~g} \mathrm{~cm}$ $\left.{ }^{3}\right)$ versus CF5 $\left(1.04 \mathrm{~g} \mathrm{~cm}^{-3}\right.$ ) (Table 3). Meanwhile, SP tends to increase by $13.85 \%$ during OF5 (26.88\%) (Table 3$)$, however, it was not statistically significant, $0.40(\alpha=0.05)$ (Table 5).

The application of OF has a beneficial effect on improving the chemical properties of the soil since the CEC and total $N$ increased significantly in OF5. Table 5 shows the significance of the correlation of the implementation of OF system with total $N(0.86, \alpha=0.05)$ and $\operatorname{CEC}(0.88, \alpha=0.05)$. The increase in chemical properties of the soil is closely related to OF as a source of soil organic $C$. The soil CEC increased significantly by $22.35 \%$ in OF5 10.90 me $100 \mathrm{~g}^{-1}$ compared with CF 8.98 me $100 \mathrm{~g}^{-1}$ (Table 4). Also, the CEC shows the soil's ability to hold and exchange it, including plant nutrients. Furthermore, the addition of organic matter increases the negative charge in the soil thereby increasing the soil CEC. The CEC for soil organic matter varies between 200 and 300 me $100 \mathrm{~g}^{-1}$, whereas the CEC value for clay only ranges from 10 (clay oxide) to 100 me $100 \mathrm{~g}^{-1}$ (type 2:1 clay); hence, the soil organic matter CEC value is 2-20 times its clay. However, the organic matter is small and has a large influenced on soil CEC. Thus, the higher the soil organic matter, the higher the soil CEC (Sparks et al., 2020).

Soil $\mathrm{N}$ produced different effect, which in OF has consistently lower values than in CF (Table 4). In OF1, the $\mathrm{N}$ content $(0.25 \%)$ decreased significantly by $34.78 \%$ compared with that in CF (0.33\%). Moreover, it was tended to increase in OF3 and OF5, but was not significantly different. This result is in line with Herencia et al. (2020), in which nitrogen deficiency was a frequent problem in the early period of OF application.

SR as a biological property signifies accretion in OF, and OF5 (76.90 mg- $\mathrm{CO}_{2} \mathrm{~kg}^{-1}$ day $^{-1}$ ) significantly increased SR by $38.45 \%$ in comparison with CF (54.80 mg-CO $\mathrm{kg}^{-1} \mathrm{day}^{-1}$ ) (Table 4). However, based on the correlation value in Table 5, the increase in the value of SR remains insignificant $(r=0.55)$. The increase in SR characterizes increased microbial activity (Mackay et al., 2021; Nabiollahi et al., 2018).

Figure 2 shows the results of vegetable production in the research conducted. Figure 2 shows that the vegetable yields in OF1 and OF3 were significantly lower than in CF at 17.08 and 20.42 tons ha $^{-1}$, respectively. However, in OF5, vegetable crop production has increased back to 26.70 tons $\mathrm{ha}^{-1}$ and almost equaled the production in CF at 27.33 tons $\mathrm{ha}^{-1}$. The correlation of the implementation of OF with the crop yields was highly significant $(r=0.92 ; p=0.01$ ) (Table 5). The increase in organic agricultural yields is related to increasing soil organic $\mathrm{C}$ content, since it supports the organic matter decomposition process, thereby releasing nutrients required for plant growth. 
The relationship between yield and soil quality was analyzed through correlation and regression tests, and there was a significant relationship from $\mathrm{P}<0.05$ to $\mathrm{P}<0.01$ between the chisel yield and soil quality such as SOC, total $\mathrm{N}$, CEC, and FC. The results showed that out of the 10 variables tested, only four have a close relationship with those of Chinese cabbage, which include total N, C, CEC, and FC, via a multiple regression estimation model as follows: $Y$ (yield $)=$ $4.21+8.20 \mathrm{~N}+6.50 \mathrm{C}+0.66 \mathrm{CEC}+0.35 \mathrm{FC},\left(\mathrm{R}^{2}=0.98 * *\right)$. The regression equation showed an increase in yield of Chinese cabbage in organic and conventional agriculture of approximately $98 \%$ and is influenced by SOC, total N, CEC, and soil water content. The nitrogen variable shows the highest contribution, followed by SOC, moisture content, and CEC.

The high contribution of $\mathrm{N}$ in increasing the vegetable yield of Chinese cabbage is an essential element for the vegetative growth of plants, whereas unstable carbon is a nutrient for plant and microbial growth because of its original chemical composition and its fast decomposition rate (Nurhidayati et al., 2018). Moreover, unstable carbon is highly essential in maintaining the status of organic matter in the soil, which acts as a source and sinks for nutrient availability (Hairiah et al., 2000; Olorunfemi et al., 2020). The CEC is important for soil fertility, and it shows the ability of the soil to hold cations and exchange these cations, including plant nutrient cations, which makes them more available to plants. Thus, soil water content shows the ability of the soil to hold water, increasing its availability for plant growth.

Soil quality status as measured using the SQR shows t OF tends to provide a lower SQR value compared with CF. SQR is the accumulation of limiting factors for soil properties, and the lower the SQR value, the less the limiting factor for soil properties, which means that it has better quality. OF5 gives the lowest SQR value, which is 20 or in the good category. Meanwhile, CF and OF1 and OF3 provide SQR values ranging from 24 to 25 or including the moderate category. Good quality means that the agricultural practice is compatible with sustainable agriculture, and moderate-quality means that a high input is needed; therefore, the agricultural practice is sustainable (Nabiollahi et al., 2018).

The difference in SQR was caused by the parameters of organic C, CEC, nutrient availability, SP, and FC, which were significantly different between organic and conventional agriculture. Meanwhile, other soil parameters such as BD, texture, BS, and soil $\mathrm{pH}$ had no significant effect on the SQR value. These results are assumed to be related to the application of OF, which has not optimally improved soil properties because of the long duration taken to change the soil properties. The soil type in this research area, Andosol soil, has a good $\mathrm{pH}$, content weight, and family planning properties. Thus, it is not a limiting factor for plant growth.

\section{Conclusion}

The application of the OF5 system satisfies the sustainability criteria, with no high input required. Soil moisture at the field capacity, organic $C$ and CEC, and SR in this system are significantly higher than those in the other systems. The advantage is that this organic system does not require high input and the soil quality is improving. The periodic assessment of the OF performance is important to be determined in the future.

\section{Declaration of Competing Interest}

The authors declare no competing financial or personal interests that may appear and influence the work reported in this paper.

\section{References}

Abrougui, K., Gabsi, K., Mercatoris, B., Khemis, C., Amami, R., \& Chehaibi, S. (2019). Prediction of organic potato yield using tillage systems and soil properties by artificial neural network (ANN) and multiple linear regressions (MLR). Soil and Tillage Research, 190, 202208. https://doi.org/10.1016/j.still.2019.01.011

Assunção, S. A., Pereira, M. G., Rosset, J. S., Berbara, R. L. L., \& García, A. C. (2019). Carbon input and the structural quality of soil organic matter as a function of agricultural management in a tropical climate region of Brazil. Science of The Total Environment, 658, 901911. https://doi.org/10.1016/j.scitotenv.2018.12.271

Bakhshandeh, E., Francaviglia, R., \& Renzi, G. (2019). A cost and time-effective method to evaluate soil microbial respiration for soil quality assessment. Applied Soil Ecology, 140, 121-125. https://doi.org/10.1016/j.apsoil.2019.04.023

Boone, L., Roldán-Ruiz, I., Van linden, V., Muylle, H., \& Dewulf, J. (2019). Environmental sustainability of conventional and organic farming: Accounting for ecosystem services in life cycle assessment. Science of The Total Environment, 695,

133841. https://doi.org/10.1016/j.scitotenv.2019.133841

Chabert, A., \& Sarthou, J.-P. (2020). Conservation agriculture as a promising trade-off between conventional and organic agriculture in bundling ecosystem services. Agriculture, Ecosystems \& Environment, 292, 106815. https://doi.org/10.1016/j.agee.2019.106815

Das, A., Patel, D. P., Kumar, M., Ramkrushna, G. I., Mukherjee, A., Layek, J., Ngachan, S. V., \& Buragohain, J. (2017). Impact of seven years of organic farming on soil and produce quality and crop yields in eastern Himalayas, India. Agriculture, Ecosystems \& Environment, 236, 142-153. https://doi.org/10.1016/j.agee.2016.09.007

Domínguez-Haydar, Y., Velásquez, E., Carmona, J., Lavelle, P., Chavez, L. F., \& Jiménez, J. J. (2019). Evaluation of reclamation success in an open-pit coal mine using integrated soil physical, chemical and biological quality indicators. Ecological Indicators, 103, 182-193. https://doi.org/10.1016/j.ecolind.2019.04.015

Franzluebbers, A. J., \& Veum, K. S. (2020). Comparison of two alkali trap methods for measuring the flush of $\mathrm{CO} 2$. Agronomy Journal, 112(2), 1279-1286. https://doi.org/10.1002/agj2.20141

Ge, Y., \& Wu, H. (2020). Prediction of corn price fluctuation based on multiple linear regression analysis model under big data. Neural Computing and Applications, 
32(22),

16843-16855.

https://doi.org/10.1007/s00521-018-03970-4

Ghaemi, M., Astaraei, A. R., Emami, H., Nassiri Mahalati, M., \& Sanaeinejad, S. H. (2014). Determining soil indicators for soil sustainability assessment using principal component analysis of astan quds- east of mashhad- Iran. Journal of soil science and plant nutrition, 14, 1005-1020. http://www.scielo.cl/scielo.php?script=sci_arttext\&pi $\mathrm{d}=$ S0718-95162014000400017\&nrm=iso

Gu, J.-D., \& McGill, W. B. (2017). Microbial biomass C and N dynamics, and $15 \mathrm{~N}$ incorporation into microbial biomass under faba bean, canola, barley, and summer fallow in a Gray Luvisol. Applied Environmental Biotechnology, 2(1), 4657. https://doi.org/10.26789/AEB.2017.01.007

Güldner, D., \& Krausmann, F. (2017). Nutrient recycling and soil fertility management in the course of the industrial transition of traditional, organic agriculture: The case of Bruck estate, 1787-1906. Agriculture, Ecosystems \& Environment, 249, 80-90. https://doi.org/10.1016/j.agee.2017.07.038

Hairiah, K., Van Noordwijk, M., \& Cadisch, G. (2000). Crop yield, $\mathrm{C}$ and $\mathrm{N}$ balance of three types of cropping systems on an Ultisol in Northern Lampung. NJAS Wageningen Journal of Life Sciences, 48(1), 3-17. https://doi.org/10.1016/S1573-5214(00)80001-9

Herencia, J., Pérez-Romero, L., Daza, A., \& Arroyo, F. (2020). Chemical and biological indicators of soil quality in organic and conventional Japanese plum orchards. Biological Agriculture \& Horticulture, 1-20.

Jiang, X., Zou, B., Feng, H., Tang, J., Tu, Y., \& Zhao, X. (2019). Spatial distribution mapping of $\mathrm{Hg}$ contamination in subclass agricultural soils using GIS enhanced multiple linear regression. Journal of Geochemical Exploration, 196,

1-7. https://doi.org/10.1016/j.gexplo.2018.10.002

Kadam, A. K., Wagh, V. M., Muley, A. A., Umrikar, B. N., \& Sankhua, R. N. (2019). Prediction of water quality index using artificial neural network and multiple linear regression modelling approach in Shivganga River basin, India. Modeling Earth Systems and Environment, 5(3), 951-962. https://doi.org/10.1007/s40808-019-00581-3

Lee, Y., Jung, C., \& Kim, S. (2019). Spatial distribution of soil moisture estimates using a multiple linear regression model and Korean geostationary satellite (COMS) data. Agricultural Water Management, 213, 580-593. https://doi.org/10.1016/j.agwat.2018.09.004

Liu, Z., Dugan, B., Masiello, C. A., \& Gonnermann, H. M. (2017). Biochar particle size, shape, and porosity act together to influence soil water properties. PLoS One, 12(6), e0179079. https://journals. plos.org/plosone/article?id=10.1371/ journal.pone.0179079

Mackay, A. D., Vibart, R., McKenzie, C., Costall, D., Bilotto, F., $\&$ Kelliher, F. M. (2021). Soil organic carbon stocks in hill country pastures under contrasting phosphorus fertiliser and sheep stocking regimes, and topographical features. Agricultural Systems, 186, 102980. https://doi.org/10.1016/j.agsy.2020.102980

Maini, A., Sharma, V., \& Sharma, S. (2020). Assessment of soil carbon and biochemical indicators of soil quality under rainfed land use systems in North Eastern region of Punjab, India. Carbon Management, 11(2), 169-182. https://doi.org/10.1080/17583004.2020.1721976

Nabiollahi, K., Golmohamadi, F., Taghizadeh-Mehrjardi, R., Kerry, R., \& Davari, M. (2018). Assessing the effects of slope gradient and land use change on soil quality degradation through digital mapping of soil quality indices and soil loss rate. Geoderma, 318, 16-28. https://doi.org/10.1016/j.geoderma.2017.12.024

Nurhidayati, N., Machfudz, M., \& Murwani, I. (2018). Direct and residual effect of various vermicompost on soil nutrient and nutrient uptake dynamics and productivity of four mustard Pak-Coi (Brassica rapa L.) sequences in organic farming system. International Journal of Recycling of Organic Waste in Agriculture, 7(2), 173-181. https://doi.org/10.1007/s40093-0180203-0

Obour, P. B., Jensen, J. L., Lamandé, M., Watts, C. W., \& Munkholm, L. J. (2018). Soil organic matter widens the range of water contents for tillage. Soil and Tillage Research, 182, 57-65. https://doi.org/10.1016/j.still.2018.05.001

Olorunfemi, I. E., Fasinmirin, J. T., Olufayo, A. A., \& Komolafe, A. A. (2020). Total carbon and nitrogen stocks under different land use/land cover types in the Southwestern region of Nigeria. Geoderma Regional, 22, e00320. https://doi.org/10.1016/j.geodrs.2020.e00320

Patil, S., Reidsma, P., Shah, P., Purushothaman, S., \& Wolf, J. (2014). Comparing conventional and organic agriculture in Karnataka, India: Where and when can organic farming be sustainable? Land Use Policy, 37, 40-51.

https://doi.org/10.1016/j.landusepol.2012.01.006

Reganold, J. P., \& Wachter, J. M. (2016). Organic agriculture in the twenty-first century. Nature Plants, 2(2), 15221. https://doi.org/10.1038/nplants.2015.221

Röös, E., Mie, A., Wivstad, M., Salomon, E., Johansson, B., Gunnarsson, S., Wallenbeck, A., Hoffmann, R., Nilsson, U., Sundberg, C., \& Watson, C. A. (2018). Risks and opportunities of increasing yields in organic farming. A review. Agronomy for Sustainable Development, 38(2), 14. https://doi.org/10.1007/s13593-018-0489-3

Sardiana, I., Adnyana, I., Manuaba, I., \& Agung, I. (2014). Soil organic carbon, labile carbon and organic carbon storage under organic and conventional systems of Chinese cabbage in Baturiti, Bali Indonesia. Journal of Biology, Agriculture and Healthcare, 4(12), 63-71. https://www.iiste.org/Journals/index.php/JBAH/articl e/view/12947

Seufert, V., Ramankutty, N., \& Foley, J. A. (2012). Comparing the yields of organic and conventional agriculture. Nature, 485(7397), 229-232. https://doi.org/10.1038/nature11069 
Sihi, D., Dari, B., Sharma, D. K., Pathak, H., Nain, L., \& Sharma, O. P. (2017). Evaluation of soil health in organic vs. conventional farming of basmati rice in North India. Journal of Plant Nutrition and Soil Science, 180(3), 389406. https://doi.org/10.1002/jpln.201700128

Singh, A. K., Dhanapal, S., \& Yadav, B. S. (2020). The dynamic responses of plant physiology and metabolism during environmental stress progression. Molecular Biology Reports, $47(2)$ https://doi.org/10.1007/s11033-019-05198-4

Skinner, C., Gattinger, A., Krauss, M., Krause, H.-M., Mayer, J., van der Heijden, M. G. A., \& Mäder, P. (2019). The impact of long-term organic farming on soil-derived greenhouse gas emissions. Scientific Reports, 9(1), 1702. https://doi.org/10.1038/s41598-018-38207-w
Sparks, D. L., Page, A., Helmke, P., \& Loeppert, R. H. (2020). Methods of soil analysis, part 3: Chemical methods (Vol. 14). John Wiley \& Sons.

Srivastava, R., Mohapatra, M., \& Latare, A. (2020). Impact of land use changes on soil quality and species diversity in the Vindhyan dry tropical region of India. Journal of $\begin{array}{lll}\text { Tropical } & \text { Ecology, 36(2), }\end{array}$ https://doi.org/10.1017/S0266467419000385

Zhang, M., Cheng, G., Feng, H., Sun, B., Zhao, Y., Chen, H., Chen, J., Dyck, M., Wang, X., Zhang, J., \& Zhang, A. (2017). Effects of straw and biochar amendments on aggregate stability, soil organic carbon, and enzyme activities in the Loess Plateau, China. Environmental Science and Pollution Research, 24(11), 10108-10120. https://doi.org/10.1007/s11356-017-8505-8 